$\int_{\mathcal{G}}^{\text {Semantics \& Pragmatics Volume 12, Article 13: 1-19, } 2019}$

\title{
Anankastic conditionals are still a mystery*
}

\author{
Milo Phillips-Brown \\ Massachusetts Institute of \\ Technology
}

Submitted 2018-01-18 / First decision 2018-03-29 / Revision received 2018-08-04 / Accepted 2018-11-12 / Final version received 2019-04-11 / Published 2019-11-15 / Final typesetting 2023-02-14

\begin{abstract}
If you want to go to Harlem, you have to take the A train' doesn't look special. Yet a compositional account of its meaning, and the meaning of anankastic conditionals more generally, has proven an enigma. Semanticists have responded by assigning anankastics a unique status, distinguishing them from ordinary indicative conditionals. Condoravdi \& Lauer (2016) maintain instead that "anankastic conditionals are just conditionals." I argue that Condoravdi and Lauer don't give a general solution to a well-known problem: the problem of conflicting goals. They rely on a special, "effective preference" interpretation for want on which an agent cannot want two things that conflict with her beliefs. A general solution, though, requires that the goals cannot conflict with the facts. Condoravdi and Lauer's view fails. Yet they show, I believe, that previous accounts fail too. Anankastic conditionals are still a mystery.
\end{abstract}

Keywords: anankastic conditionals, desire ascriptions, teleological modality, effective preferences, conflicting desires

\section{Introduction}

The Harlem Sentence, just below, doesn't look special.

(1) If you want to go to Harlem, you have to take the A train. ${ }^{1}$

* Thank you to Neil Banerjee, Marion Boulicault, David Boylan, Keny Chatain, Nilanjan Das, Isa Kerem, Justin Khoo, Matthew Mandelkern, Ginger Schultheis, and two anonymous reviewers for your help. Thank you especially to Kai von Fintel and Magdalena Kaufmann for extraordinary guidance and encouragement.

1 The name is from von Fintel \& Iatridou 2005 and the sentence from Sæbø 2001.

(C)2019 Milo Phillips-Brown

This is an open-access article distributed under the terms of a Creative Commons Attribution License (https://creativecommons.org/licenses/by/3.o/). 
It's clear what the sentence means, more or less, that taking the A train is necessary for going to Harlem. Yet a compositional account of its meaning, and the meaning of anankastic conditionals more generally, has proven an enigma.

Semanticists have assigned anankastics a unique status, developing accounts that distinguish them from ordinary indicative conditionals. Following Huitink (2008), Condoravdi \& Lauer (2016) disagree, maintaining that, as their title says, "anankastic conditionals are just conditionals." I argue that Condoravdi and Lauer's account fails in the face of a well-known problem, the problem of conflicting goals. Their proposed solution to the problem works in certain cases: they rely on a special, effective preference interpretation for want on which what an agent wants cannot conflict with her beliefs. But a general solution requires that the goals cannot conflict with the facts. And so Condoravdi and Lauer's view doesn't work in all cases - indeed, I argue that it doesn't work in the most common cases.

In addition to proposing their semantics for anankastics, Condoravdi and Lauer introduce data of conditionals ('near-anankastics') that aren't anankastics but that nonetheless have the same compositionality problem as anankastics. The accounts previously given for anankastics, Condoravdi and Lauer argue (and I agree), do not generalize to near-anankastics. These accounts fail. And, I argue, so does Condoravdi and Lauer's. Anankastic conditionals are still a mystery.

I'll start by explaining the initial compositionality problem, what I'm calling the problem of conditioning on goals, and show how it's dissolved by Condoravdi and Lauer, who take their lead from Huitink. I'll then lay out the problem of conflicting goals, Condoravdi and Lauer's proposed solution, and my argument against it. I'll consider, and ultimately reject, replies on Condoravdi and Lauer's behalf, as well as a different possible solution to the problem of conflicting goals.

\section{The problem of conditioning on goals}

Identified by Sæbø $(1985,2001)$, the problem of conditioning on goals is that the most straightforward application of Kratzer's $(1981,1991)$ classic system of modals and conditionals gets anankastics wrong.

In Kratzer's system, modals are evaluated against two conversational backgrounds, a modal base $f$ and ordering source $g$, both functions from 
Anankastic conditionals are still a mystery

worlds to sets of propositions. Leaving the familiar details to a footnote, the semantics for necessity modals generally, and have to in particular, is: ${ }^{2}$

$$
\begin{aligned}
& \llbracket \text { have to } \rrbracket^{w}(f)(g)\left(\lambda w \cdot \llbracket \mathbf{q} \rrbracket^{w}\right)=1 \text { iff } \\
& \forall w^{\prime} \in \operatorname{best}_{g(w)}(\bigcap f(w)): \llbracket \mathbf{q} \rrbracket^{w^{\prime}}=1 .
\end{aligned}
$$

If modifies a modal base:

$$
\llbracket \text { if } r \rrbracket(f)=\lambda w \cdot f(w) \cup\left\{\lambda w \cdot \llbracket r \rrbracket^{w}\right\} .
$$

Combining if and have to gives us:

$$
\begin{aligned}
& \llbracket \text { have to } \rrbracket^{w}(\llbracket \text { if } \mathbf{r} \rrbracket(f))(g)\left(\lambda w . \llbracket \mathbf{q} \rrbracket^{w}\right)=1 \text { iff } \\
& \forall w^{\prime} \in \operatorname{best}_{g(w)}\left(\bigcap\left(f(w) \cup\left\{\lambda w . \llbracket \mathbf{r} \rrbracket^{w}\right\}\right)\right): \llbracket \mathbf{q} \rrbracket^{w^{\prime}}=1 .
\end{aligned}
$$

An anankastic conditional contains a teleological modal. Its ordering source provides certain relevant goals, its modal base certain relevant facts. Later, we'll consider what these goals and facts are. To see the problem of conditioning on goals, we can just stipulate the goals and facts.

The problem is this. Suppose that we're evaluating the Harlem Sentence in the actual world. Assume that throughout the modal base, various actually true propositions about New York's geography hold - that, for example, the A train is the only way to Harlem. Let the relevant goals be your actual goals, which, imagine, don't include going to Harlem. I assert the Harlem Sentence. The if-clause restricts the modal base to those worlds where you want to go to Harlem. We ask: do you take the A train in all of these worlds that best realize the relevant goals, that is, your actual goals? No - since your actual goals don't include going to Harlem! The Harlem Sentence comes out false even though the A train is the only way to Harlem.

A solution will say that when evaluating whether you have to take the A train in a world $w$, the proposition that you go to Harlem (Harlem) is a relevant goal in $w$.

\section{The first pieces of Condoravdi and Lauer's view}

Authors have solved the problem of conflicting goals in various ways. Condoravdi and Lauer solution belongs to a class of solutions that includes those of von Fintel \& Iatridou (2006) and Huitink (2008), solutions on which the

2 We get a pre-order $\leq_{g(w)}: u \leq_{g(w)} v$ iff $\{p \in g(w): p(v)=1\} \subseteq\{p \in g(w): p(u)=1\}$. And where $X$ is a set of worlds, best $_{g(w)}(X)=\left\{w^{\prime \prime} \in X: \neg \exists v \in X\left[v<_{g(w)} u\right]\right\}$. 
Harlem Sentence has a double modal structure. In addition to the overt modal, have to, there's a covert epistemic modal, nec, and it's nec, not have to, that's restricted by the if-clause. On Huitink's and Condoravdi and Lauer's views, anankastic conditionals are just ordinary indicative conditionals.

Here is the double modal structure, along with the single modal structure for contrast:

Single modal

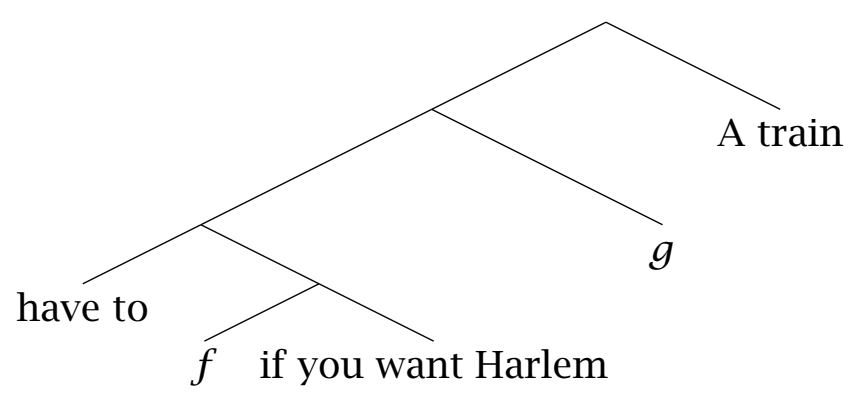

Double modal

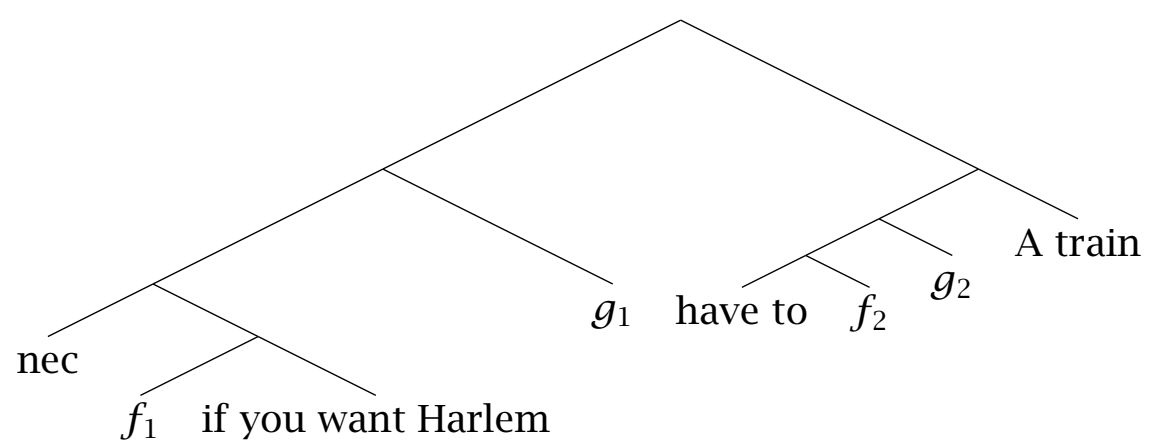

The semantics is:

$\llbracket$ nec $\rrbracket^{w}\left(\llbracket\right.$ if you want Harlem $\left.\rrbracket\left(f_{1}\right)\right)\left(g_{1}\right)\left(\lambda w . \llbracket\right.$ have to $\rrbracket^{w}\left(f_{2}\right)\left(g_{2}\right)$ $\left(\lambda w \cdot \llbracket\right.$ A train $\left.\left.\rrbracket^{w}\right)\right)$

$=1$ iff $\forall w^{\prime} \in \operatorname{best}_{g_{1}(w)}\left(\bigcap\left(f_{1}(w) \cup\left\{\lambda w . \llbracket\right.\right.\right.$ you want Harlem $\left.\left.\left.\rrbracket^{w}\right\}\right)\right)$ :

$\llbracket$ have to $\rrbracket^{w^{\prime}}\left(f_{2}\right)\left(g_{2}\right)\left(\lambda w . \llbracket \mathrm{A}\right.$ train $\left.\rrbracket^{w}\right)=1$. 
Anankastic conditionals are still a mystery

We evaluate the Harlem Sentence in a world $w$ first by identifying a set of worlds (determined nec's conversational backgrounds, $f_{1}$ and $g_{1}$ ) where you want to go to Harlem. Then we ask whether you have to take the A train in each $w^{\prime}$ in the set. Advocates of the double modal view intend that (at least in typical cases) each world in have to's modal base at $w^{\prime}, f_{2}\left(w^{\prime}\right)$, matches $w$ in its subway facts. Suppose we're evaluating the Harlem Sentence in a world $w$ where only the A train goes to Harlem. Then at each $w^{\prime}$ where we evaluate whether you have to take the A train, every world in the modal base will be one where only the A train goes to Harlem. That looks right.

Condoravdi and Lauer's double modal view is their own because of their choices for the conversational backgrounds. We'll discuss the teleological ordering source later, since that's where my criticism lies. Consider the other three conversational backgrounds now. For reasons I won't get into, Condoravdi and Lauer say that nec's modal base is epistemic, deriving from the speaker's true beliefs; nec's ordering source is one of typicality; and have to's modal base is historical. ${ }^{3}$ So far, then, we have:

First pass semantics. The Harlem Sentence is true in $w$ iff

a. For every most typical world $w^{\prime}$ compatible with the speaker's true beliefs in $w$ where you want to go to Harlem:

b. You have to take the A train in $w^{\prime}$. More precisely:

i. For every world $w^{\prime \prime}$ historically accessible from $w^{\prime}$ (each of which matches $w$ in subway fact ${ }^{4}$ ) that best conforms to the relevant goals in $w^{\prime}$ :

ii. You take the A train in $w^{\prime \prime}$.

Note: in what follows, I will ignore the typicality constraint, since the cases I discuss can be filled out so that the constraint doesn't make a difference to my point.

The problem of conditioning on goals is solved if we require that wanting to go to Harlem in a world $w^{\prime}$ entails that going to Harlem is a relevant goal in $w^{\prime}$. Then, since you want to go to Harlem in each $w^{\prime}$ where we evaluate whether you have to take the A train, going to Harlem is a relevant goal in $w^{\prime}$.

3 See their pages 46 and 47 .

4 More precisely: each of these $w^{\prime \prime}$ matches $w$ in subway fact when nothing atypical happens in $w$. 
The task is then to define the teleological ordering source in a way that entails this requirement - while avoiding the problem of conflicting goals. Condoravdi and Lauer's definition, which we'll see later, does entail the requirement; ${ }^{5}$ they solve the problem of conditioning on goals. But, I argue, the problem of conflicting goals remains.

\section{The problem of conflicting goals}

The problem of conflicting goals, which must be faced by semantics of various kinds, manifests itself differently in different frameworks. I'll bring it out by showing how it falsifies a conjunction of two views: the first pass semantics, plus a first pass definition of the teleological ordering source, one that's often floated in the literature. ${ }^{6}$

Consider:

First pass definition of the teleological ordering source

If you want $p$ in $w$, then $p \in g_{2}(w)$, the relevant goals in $w$.

This definition does rightly entail that if Harlem is wanted, then Harlem is a goal. And it's natural to think that in evaluating what you have to do, what you want matters.

The problem is that we'll predict that the Harlem Sentence is false when it is intuitively true - in a case inspired by von Fintel \& Iatridou's (2005) Hoboken Scenario. The prediction of falsehood follows purely from a supposition about the speaker's beliefs about the agent's desires, and not from any facts about the subway.

The supposition couldn't be more common: that the speaker leaves open that you, the agent, have two desires that can't both be realized. More specifically, the speaker leaves open that you want to go to Harlem and want to do something else - say, go to Hoboken - that precludes going to Harlem. There is some world $w^{\prime}$ compatible with the speaker's beliefs where you both want to go to Harlem and to Hoboken, but can't go to both in $w^{\prime}$. (The speaker needn't believe that the agent has two desires that can't both be satisfied, nor need the agent in fact have two desires that can't be satisfied; it's merely that the speaker's beliefs leave open that possibility.)

5 To be precise, it entails a restricted version of this requirement. See page 9.

6 See e.g., Sæbø 2001 and von Fintel \& Iatridou 2005. Sæbø 2020 states it explicitly. 
Anankastic conditionals are still a mystery

\section{New Hoboken Scenario ${ }^{7}$}

a. The A train is the only way to Harlem.

b. In some world $w^{\prime}$ compatible with the speaker's beliefs: you want in $w^{\prime}$ to go to both Harlem and Hoboken, but you can't go to both in $w^{\prime}$.

I assert the Harlem Sentence. According to the first pass semantics, the sentence is false if there's a world $w^{\prime}$ compatible with my (the speaker's) true beliefs where you want to go to Harlem but do not have to take the A train. (Remember, we're ignoring the typicality constraint.) There is such a $w^{\prime}$.

There's a world $w^{\prime}$ compatible with my beliefs - and thereby my true beliefs - where you want to go to both Harlem and Hoboken. The first pass definition of the teleological ordering source dictates that the relevant goals in $w^{\prime}$ include both Harlem and Hoboken (the proposition that you go to Hoboken). So, in some of the best worlds in the modal base at $w^{\prime}$ you go to Harlem, and in some you go to Hoboken. In none do you go to both, since you cannot go to both in $w^{\prime}$. Supposing that the A train doesn't go to Hoboken in $w^{\prime}$, it follows that you do not take the A train in all of the best worlds in the modal base in $w^{\prime}$. You do not have to take the A train in $w^{\prime}$. The Harlem Sentence is predicted false.

But it is true. Taking the A train is necessary for going to Harlem. We've assumed nothing else that (it seems) should bear on the truth of the Harlem Sentence. (Recall that as a first approximation, the sentence means just this: that taking the A train is necessary for going to Harlem.) Our only other assumption is that it's compatible with my beliefs that you want two things that can't both be realized - in particular, going to Harlem and to Hoboken. And it couldn't be more normal leave this possibility open. All of us, all the time, want two things that can't both be realized.

Abstracting away from the particularities of the semantics here, the problem of conflicting goals at its core is this. In some world $w^{\prime}$ where we evaluate whether you have to take the A train, there are two goals in $w^{\prime}$, Harlem and

7 The original Hoboken scenario in von Fintel \& Iatridou 2005 is like the New Hoboken Scenario in that the A train is the only way to Harlem. It differs in that the speaker's beliefs about the compatibility of the agent's desire are not part of the scenario; rather, it's the compatibility of the agent's desires themselves. In their 2005, von Fintel and Iatridou stipulate that you (the agent) in fact want to go to both Harlem and Hoboken, but in fact cannot go to both. (In footnote 11, I give a counterexample to Condoravdi and Lauer that closely resembles the original Hoboken Scenario.) 
Hoboken, that are jointly inconsistent with the facts in $w^{\prime}$ - there are two goals that conflict with the facts.

\section{Condoravdi and Lauer's view in full}

Recall that Condoravdi and Lauer and Huitink both solve the problem of conditioning on goals by positing a certain double modal structure. They also share a basic approach to the problem of conflicting goals, an approach on which want gets a special interpretation. They differ, though, on what that interpretation is. Condoravdi and Lauer's interpretation is situated in a new semantics for want.

I won't canvas the parts of their semantics not directly related to anankastics. We'll focus on their contention that want is sometimes interpreted against a special contextual parameter, $E P$, which represents what they call an agent's effective preferences. Wanting $p$ in the effective preference sense for short, wanting $E_{E P} p$-means that your desire for $p$ is guiding your action. You might want to play in the NBA, but, knowing that's unattainable, your desire doesn't guide your action. You want to play in the NBA, but you don't want $_{E P}$ to play in the NBA. Or you might want to sleep, but want to go running more, and when you run, it's your latter desire that guides your action. Although you wanted to sleep, you didn't want ${ }_{E P}$ to sleep. What you did want ${ }_{E P}$ was to run.

Wanting $_{E P}$ is tightly linked to planning and intending. You want to play in the NBA, but you don't plan or intend to. You wanted to sleep, but it's running that you intended and planned to do. A close relative of wanting $E_{E P}$, called volitive wanting, has long been discussed by philosophers (Davis (1984), from whom Condoravdi and Lauer take their cue, reviews the literature). Those who subscribe to the notion - and many do not - think that whatever you intend or plan to do, you can be truly said to want to do.

The crucial part of Condoravdi and Lauer's view is that you can't want ${ }_{E P}$ two things that conflict with your beliefs. ${ }^{8}$ More precisely: if you want want ${ }_{E P}$ $p$ and want ${ }_{E P} q$, you must believe that $p$ and $q$ can both be achieved $-p$ and $q$ must be jointly consistent with your beliefs. ${ }^{9}$ This constraint is motivated

8 Other semantics, including Heim's (1992) and von Fintel's (1999), also disallow wanting two things that conflict with your beliefs.

9 This follows from Condoravdi and Lauer's stipulation that, in their terminology, the preferential structure that represents an agent's effective preferences in a given world obeys the consistency and realism constraints relative to her belief set (see their pages 29-31). 
Anankastic conditionals are still a mystery

in part by the idea that you can't be planning, or intending, to do two things that you believe cannot both be done (see Condoravdi and Lauer's pages 22-3 for more motivation). ${ }^{10}$ For example, consider how strange it would be for someone to say:

(2) \# I'm planning on going to Seattle tonight and I'm planning on going to Melbourne tonight, and I believe I can't do both.

Condoravdi and Lauer say that it's the effective-preference interpretation of want at play in anankastics:

(3) If you want ${ }_{E P}$ to go to Harlem, you have to take the A train.

And the goals aren't merely what's wanted, as the first pass definition of the ordering source has it. Rather, they're what's wanted ${ }_{E P}$ :

Condoravdi and Lauer's definition of the teleological ordering source $p \in g_{2}(w)$ if and only if you want $\underline{w_{E P}} p$ in $w$.

We can now lay out Condoravdi and Lauer's view in full. Adopting their nomenclature, $f_{\text {Sbel }}$ is the speaker's-true-beliefs modal base, $g_{t y p}$ is the typicality ordering source, and $f_{\text {hist }}^{t}$ is the historical modal base. The effective preference ordering source, $g_{E P_{y o u}}$, is this:

$g_{E P_{\text {you }}}(w)$ contains exactly those propositions you want ${ }_{E P}$ in $w$.

So we have:

\section{Condoravdi and Lauer's logical form}

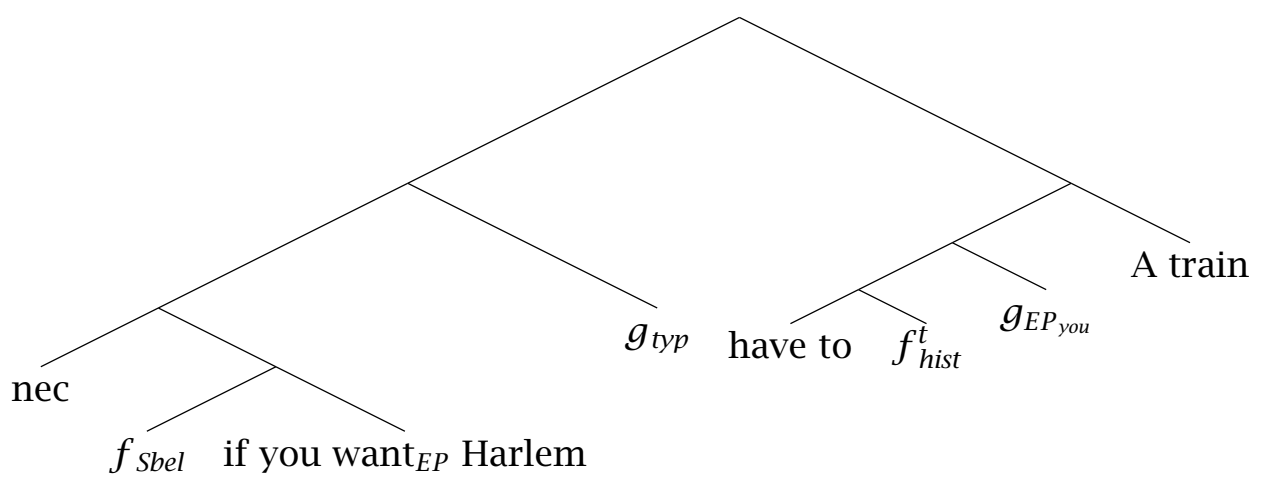

10 This idea is a consequence of Grano's (2017) semantics for intend, which makes key use of effective preferences (see his pages 13-14). 
Condoravdi and Lauer's semantics. The Harlem Sentence is true in $w$ iff

a. For every most typical world $w^{\prime}$ compatible with the speaker's true beliefs in $w$ where you want ${ }_{E P}$ to go to Harlem:

b. You have to take the A train in $w^{\prime}$. More precisely:

i. For every world $w^{\prime \prime}$ historically accessible from $w^{\prime}$ (each of which matches $w$ in subway facts) that best conform to what you want $E P$ in $w^{\prime}$ :

ii. You take the A train in $w^{\prime \prime}$.

Focus on wanting ${ }_{E P}$, since we've already reviewed everything else. Condoravdi and Lauer identify the goals with what's wanted ${ }_{E P}$ in order to solve the problem of conflicting goals. After all, wanting $E_{E P}$ is already conflict-free.

This identification works in certain cases. Take some world $w^{\prime}$ where we're evaluating whether you have to take the A train. Suppose that in $w^{\prime}$ you believe that it's impossible to go to both Harlem and Hoboken. Then, by the anti-conflict constraint on wanting $E_{E P}$, you cannot both want ${ }_{E P}$ to go to Harlem and want ${ }_{E P}$ to go to Hoboken. Since the goals in $w^{\prime}$ are what you want $_{E P}$ in $w^{\prime}$, Harlem and Hoboken cannot both be among the goals! Your belief that Harlem and Hoboken conflict prevents the goals from containing two propositions that conflict with the facts.

\section{The return of the problem of conflicting goals}

To repeat: on Condoravdi and Lauer's view, the goals in a world $w^{\prime}$ won't contain both Harlem and Hoboken when you the agent believe that you can't get to both Harlem and Hoboken in $w^{\prime}$. The problem is that you don't have this belief in every world. In some worlds, you believe that it's possible for you to go to both Hoboken and Harlem. Regardless of whether Harlem and Hoboken conflict with the facts in such worlds, the anti-conflict constraint on wanting $E_{E P}$ - which, to reiterate, bars conflict with your beliefs - doesn't kick in, meaning that you can want ${ }_{E P}$ to go to both Harlem and Hoboken. Harlem and Hoboken can both be among the goals. The goals can conflict with the facts. That is the primary thesis of this paper.

We have the structural flaw in Condoravdi and Lauer's proposed solution to the problem of conflicting goals. Now consider a case, a modification of the New Hoboken Scenario, where the flaw is manifested. The Harlem Sentence is true, but it is predicted false. The prediction of falsehood follows entirely 
Anankastic conditionals are still a mystery

from a supposition about the speaker's beliefs about the agent's plans (effective preferences) and beliefs, and not from any fact about the subway.

As in the New Hoboken Scenario, the supposition could not be more common: the speaker leaves open that you, the agent, have two plans (two things you want ${ }_{E P}$ ) that can't both be realized. More specifically, the speaker leaves open that you plan to go to Harlem and plan to do something else - say, go to Hoboken - that precludes going to Harlem. There is some world $w^{\prime}$ compatible with the speaker's beliefs where you plan (want $\left.{ }_{E P}\right)$ to go both to Harlem and to Hoboken, but can't go to both in $w^{\prime}$. (The speaker needn't believe that the agent has two plans that can't both be carried out, nor need the agent in fact have two plans that can't both be carried out; it's merely that the speaker's beliefs leave open that possibility.)

\section{Newer Hoboken Scenario}

a. The A train is the only way to Harlem.

b. In some world $w^{\prime}$ compatible with the speaker's beliefs: you want ${ }_{E P}$ in $w^{\prime}$ to go to both Harlem and Hoboken, but you can't go to both in $w^{\prime}$.

We have this world $w^{\prime}$ where you want ${ }_{E P}$ to go to both Harlem and Hoboken. Since the goals are supposed to be what's wanted w $_{E P}$, the goals in $w^{\prime}$ include Harlem and Hoboken, which conflict with the facts in $w^{\prime}$. (We are as before ignoring the typicality constraint.) As we know, when the goals conflict with the facts, the Harlem Sentence is predicted false.

But it is true. Taking the A train is necessary for going to Harlem. And, as before, we've assumed nothing else that (it seems) should bear whether the sentence is true. (Recall again that as a first approximation, the sentence means that taking the A train is necessary for going to Harlem.)

The Newer Hoboken Scenario is not a corner case. Its key assumption concerns structure of the speaker's belief state, and that structure is shared by speakers in most cases where anankastics are asserted: the speaker leaves open the possibility that the agent has two plans (effective preferences) that cannot both be realized.

More specifically, the speaker leaves open that the agent simultaneously plans to achieve the hypothetical goal of the anankastic (e.g., going to Harlem) and plans to do to do something else - say, go to Hoboken - that precludes going to Harlem. As noted above, the speaker needn't believe that the agent has such plans. And, crucially, the speaker needn't have any particular plan in mind that could conflict with going to Harlem. The speaker need only leave 
open that the agents has some plan or other that could conflict with going to Harlem.

For a speaker not to leave open such a possibility would be for her to believe that the agent is so knowledgeable about the world - so good at accounting for every possible eventuality - that certain of her plans cannot conflict. In most cases, none of us are so knowledgeable. In most cases, speakers assume their addresses aren't so knowledgeable. In most cases, then, when a speaker asserts an anankastic, the structure of her belief state matches that of the speaker's in the Newer Hoboken Scenario.

To sum up: the goals may conflict when the agent's effective preferences conflict with the facts. And for Condoravdi and Lauer's view to fail, the agent's effective preferences needn't actually conflict with the facts. Rather, as will commonly be the case, the speaker just needs to leave open the possibility that they do.

\section{Replies on Condoravdi and Lauer's behalf? (Looks like not)}

Condoravdi and Lauer do recognize that identifying the goals with what's wanted $_{E P}$ does not guarantee that the goals don't conflict with the facts. They say two things about this, neither of which, I argue, will save their view.

First, they write:

Generally and by default [the speaker] can assume that the agent is sufficiently informed about the relevant facts, so as to not have incompatible effective preferences (given the facts). (p. 49)

If this were indeed the default assumption, we should be suspicious of the Newer Hoboken Scenario. In it, I the speaker violate the assumption! I leave open the possibility that you the agent have incompatible effective preferences - in other words, that you want ${ }_{E P}$ two things that conflict with the facts. A case that violates a default assumption is a case to be wary of.

This assumption is not the default, though, nor should it be. (There are also counterexamples, which I'll leave to a footnote, that don't violate the assumption. ${ }^{11}$ ) As I pointed out in the previous section, life with limited information leads us to have plans - effective preferences - that can't all be

11 For example: (i) the A train is actually the only way to Harlem; (ii) you actually want $E P$ to go to both Harlem and Hoboken; (iii) you actually can't go to both; (iv) I do actually (and falsely) assume that you are sufficiently informed about the relevant facts. I'll leave it to you the reader to work out how this is indeed a counterexample. 
Anankastic conditionals are still a mystery

realized. Speakers know this: they leave open that their addressees have incompatible effective preferences.

Further, speakers can acknowledge that they leave open that their addressees have incompatible effective preferences. For example, I might say:

(4) If you want to go to Harlem, you have to take the A train. (But going to Harlem may mean that you'll be unable to do something else you may be planning to do. I can't know exactly what your plans are or just what might conflict with going to Harlem. $)^{12}$

Here, the speaker acknowledges in the parenthetical that she leaves open that you may have a plan - an effective preference - that conflicts with going to Harlem. Not only is (4) fine to say, it seems to go without saying. (The first sentence of the parenthetical in particular seems seems so obvious that asserting it feels condescending.)

Condoravdi and Lauer's second concern is with cases that have informational asymmetry between the speaker and the agent. Consider the following (it's the second iteration of what Condoravdi and Lauer call 'the Virus Scenario' (p. 50)).

Virus Scenario The A train is the only way to Harlem. Yet anyone who goes to Harlem will be infected by a virus that has entered the air there. You do not know about the virus, but I do. I'm not able to tell you about it right now.

a. (You:) How do I get to Harlem?

b. (Me:) You don't know all the facts, so don't do anything until I brief you in private, but if you want to go to Harlem, you have to take the A train.

Condoravdi and Lauer predict that the Harlem Sentence is false in this scenario. ${ }^{13}$ (Without running through the derivation here, it's false because the anti-conflict constraint on wanting $g_{E P}$ does not prevent conflict with the facts.) The case then appears to be a counterexample: the Harlem Sentence is predicted false in a world where the A train is the only way to Harlem.

There is something quite strange about (7), though, and the strangeness casts doubt on the import of the Virus Scenario - or so claim Condoravdi

12 Thank you to Magdalena Kaufmann for help coming up with this sentence.

13 More precisely, they predict that the Harlem Sentence is false on its anankastic interpretation. This is important for their discussion of the Virus Scenario, but we needn't trace out its implications here. 
and Lauer. The reason for the strangeness of (7), they say, is the informational asymmetry between speaker and agent. Specifically, the informational asymmetry with respect to Harlem and Not Infected, the proposition that you won't be infected. We have that: Harlem and Not Infected conflict, I know of the conflict, and you don't. Condoravdi and Lauer suggest that in general, we cannot take at face value any apparent counterexample if there's informational asymmetry at play. I'm happy to agree. (Note, though, that to my ear and that of many informants, there's nothing strange about the Harlem Sentence in the Newer Hoboken Scenario, marking a dissimilarity between the Newer Hoboken Scenario and the Virus Scenario.)

So, if there were informational asymmetry in the Newer Hoboken Scenario, we should be suspicious of whether it is indeed a counterexample. (Without going into just why, Condoravdi and Lauer would say that the place to look for informational asymmetry would be with respect to Harlem and Hoboken.)

We're free to suppose that there is no informational asymmetry with respect to Harlem and Hoboken in the Newer Hoboken Scenario. For example, we can imagine that Harlem and Hoboken actually conflict with the facts, you don't know of the conflict, and neither do . $^{14}$

It's compatible with the original description of the Newer Hoboken Scenario that Harlem and Hoboken actually conflict because the description is silent on how Harlem and Hoboken actually relate. It's silent too on your state of mind, so there's no problem with the supposition that you don't know about the conflict. Finally, the description is also compatible with my not knowing about the conflict. The only thing it says about me is that my beliefs leave open a possibility where the conflict exists but you nonetheless want $_{E P}$ to go to both. The Newer Hoboken Scenario stands as a counterexample.

14 Indeed, we can go further and suppose that as far as Harlem and Hoboken go, the speaker and agent have exactly the same knowledge and beliefs. For example, we may assume that the beliefs of the speaker and agent both leave open the possibility that Harlem and Hoboken conflict, and both leave open the possibility that they don't conflict. Further, we may imagine that speaker and agent have the exact same justification for leaving open these possibilities. All of this is compatible with the Newer Hoboken Scenario. 
Anankastic conditionals are still a mystery

\section{A different solution? (Looks like not)}

As we know, Condoravdi and Lauer address the problem of conflicting goals with a special interpretation for want. This might make you wonder: even though wanting ${ }_{E P}$ can only prevent conflict with the agent's beliefs, is there a different interpretation that prevents conflict with the facts? An interpretation on which, for example, if you want to go to Harlem, you thereby don't want to do anything else that in fact conflicts with going to Harlem, regardless of your beliefs.

While the most common interpretation of want is intimately wrapped up with the agent's beliefs - as reflected in the literature on want ${ }^{15}$ - there is another interpretation that's instead connected to the facts. To illustrate, take a case inspired by Williams 1981. Toni is about to drink from a bottle that she believes contains gin, but that in fact contains gasoline. I am aware of this. I say:

(5) Toni doesn't really want to drink from the bottle. (It contains gas!)

(6) (To Toni:) You don't really want to drink from the bottle. (It contains gas!)

With (5) and (6), Toni's beliefs aren't what's at issue: she believes that the bottle contains water, which she would enjoy. Rather, what matters are the facts: the bottle in fact contains gas, which she very much wouldn't enjoy. Intuitively, that's why (5) and (6) are true.

Following Jerzak 2019, call the interpretation of (want) in (5) and 6 the 'advisory want'. ${ }^{16}$ The hope would be that (i) what you advisory-want cannot conflict with the facts, and (ii) the advisory want is the want of anankastics. ${ }^{17}$ It's unclear whether the advisory want could prevent conflict with the facts, but even if it could, there are two problems.

First, speakers of French, Hindi, and Turkish report that their correlates of (5) and (6) are either false or infelicitous - and similarly for translations of English sentences that contain the advisory want more generally. ${ }^{18}$ All of

15 See e.g., Heim 1992 and von Fintel 1999.

16 Jerzak extensively discusses the advisory want.

17 A different approach from (ii) would be to say that want ${ }_{E P}$ is the want of anankastics, as Condoravdi and Lauer claim, but that in problem cases like the Newer Hoboken Scenario, the Harlem Sentence is not interpreted as an anankastic, but rather as a conditional with the advisory want. The objections I raise below apply just as well to this approach.

18 Here are French translations for (5) and (6), respectively: 
these speakers report that the Harlem Sentence is true in the Newer Hoboken Scenario. It would be surprising if in the Newer Hoboken Scenario the advisory want appears in the Harlem Sentence in languages in which it's otherwise absent.

Second, even in English, the advisory want can't help with all anankastics. Consider that conditionals that don't feature want at all can be interpreted as anankastics: ${ }^{19}$

(13) If you intend to go to Harlem, you have to take the A train.

(14) If you're planning on going to Harlem, you have to take the A train.

(7) Toni ne veut pas réellement boire ce qu'ily a dans cette bouteille. (Elle Toni NE wants not really drink what that-there is in that bottle. (It contient de l'essence!) contains some-of the-gas!)

'Toni doesn't really want to drink from the bottle. (It contains gas!)'

(8) $\mathrm{Tu}$ ne veux pas réellement boire ce qu'il y a dans cette bouteille. (Elle You NE want not really drink what that-there is in that bottle. (It contient de l'essence!) contains some-of the-gas!)

'You don't really want to drink from the bottle. (It contains gas!)'

The Turkish:

(9) Toni aslında o şişeden içmeyi istemiyor. (İçinde gaz var!) Toni actually that bottle-from drink want.NEG.IMPF. (Inside gas EXIST!) 'Toni doesn't really want to drink from that bottle. (It contains gas!)'

(10) Aslında o şişeden içmeyi istemiyorsun. (İçinde gaz var!) Actually that bottle-from drink want.NEG.IMPF.2SG. (Inside gas EXIST!)

'You don't really want to drink from the bottle. (It contains gas!)'

The Hindi:

(11) Toni us botal se sac mein piina nahi caahti hain. (us mein gas hain!) Toni the bottle from really drink not want to. (in it gas there is!)

'Toni doesn't really want to drink from that bottle. (It contains gas!)'

(12) Tum us botal se sac mein piina nahi caahti ho. (us mein gas hain!) You the bottle from really drink not want to. (in it gas there is!)

'You don't really want to drink from the bottle. (It contains gas!)'

19 Condoravdi and Lauer also affirm that (13) and (14) have anankastic readings (see e.g., their page 2), and they rely on the existence of intend- and plan-anankastics more generally to make various points (see their pages 20 and 23). 
Anankastic conditionals are still a mystery

As with the Harlem Sentence (which does contain want), these anankastics raise the problem of conflicting goals. With the Harlem Sentence, the relevant goals were what's wanted, in some sense or other. What are the relevant goals for (13) and (14)? At a first pass: what you intend to do and are planning to do, respectively. But in the Newer Hoboken Scenario, there's a world compatible with my beliefs where you can't go to both Harlem and Hoboken and yet you intend to both and plan to go to both (recall that wanting $E_{E P}$ is tightly connected with intending and planning). Again, the goals conflict with the facts.

We're seeing how far we can go with the idea that (i) it's the advisory want in anankastics (or at least anankastics with want) and (ii) you can't advisorywant two things that are incompatible with the facts. This would solve the problem of conflicting goals for the Harlem Sentence. But clearly it doesn't solve the problem of conflicting goals for (13) and (14). These sentences don't contain want! Further, there's no analogue of the advisory want that could apply to (13) or (14), no analogue that could resolve the problem of conflicting goals for anankastics with intend or plan more generally. Consider:

(15) \# Toni doesn't really intend to drink from the bottle.

(16) \# (To Toni:) You don't really intend to drink from the bottle.

(17) \# Toni isn't really planning to drink from the bottle.

(18) \# (To Toni:) You aren't really planning to drink from the bottle.

Even if the advisory want could help in certain cases, it can't furnish a general solution to the problem of conflicting goals.

\section{Conclusion}

Anankastic conditionals have been an enigma to semanticists, who've been led to distinguish anankastics from ordinary indicative conditionals. Condoravdi and Lauer, like Huitink, instead posit a double modal structure (thereby solving the problem of conditioning on goals) on which anankastic conditionals are just ordinary indicative conditionals.

I've argued that Condoravdi and Lauer don't have a general solution to the problem of conflicting goals. Their effective preference interpretation for want prevents conflict with the agent's beliefs. What we need, though, is to prevent conflict with the facts. When an agent is wrong about the facts, the goals may conflict. And the agent needn't actually be wrong. Condoravdi 
and Lauer's view fails whenever the speaker leaves open that the agent is wrong about certain facts (and leaves open that she has certain plans), as the speaker will in most cases.

Where does that leave us? Not somewhere good. Remember that Condoravdi and Lauer argued that previous semantics for anankastics don't generalize to near-anankastics. If Condoravdi and Lauer are right about that, and I believe that they are, then those semantics are inadequate. But so is Condoravdi and Lauer's. Although I wish that I could point to a way forward, I can't see one. Anankastic conditionals are still a mystery.

\section{References}

Condoravdi, Cleo \& Sven Lauer. 2016. Anankastic conditionals are just conditionals. Semantics \& Pragmatics 9(8). 1-69. https://doi.org/10.3765/sp. 9.8.

Davis, Wayne. 1984. The two senses of desire. Philosophical Studies 45(2). 181195. https://doi.org/10.1007/BFoo372477.

von Fintel, Kai. 1999. NPI licensing, Strawson entailment, and context dependency. Journal of Semantics 16(2). 97-148. https://doi.org/10.1093/jos/ 16.2.97.

von Fintel, Kai \& Sabine Iatridou. 2005. What to do if you want to go to Harlem: Anankastic conditionals and related matters. Manuscript, Massachusetts Institute of Technology. http://web.mit.edu/fintel/fintel-iatridou-2005\%2oharlem.pdf.

von Fintel, Kai \& Sabine Iatridou. 2006. Anankastic conditionals and related matters. Slides of talk presented at the University of Tübingen. http:// web.mit.edu/fintel/fintel-20o6-harlem-tubingen.pdf.

Grano, Thomas. 2017. The logic of intention reports. Journal of Semantics 34(4). 587-632. https://doi.org/10.1093/jos/ffxo10.

Heim, Irene. 1992. Presupposition projection and the semantics of attitude verbs. Journal of Semantics 9(3). 183-221. https://doi.org/10.1093/jos/9. 3.183 .

Huitink, Janneke. 2008. Modals, conditionals and compositionality. Nijmegen: Radboud University dissertation. http://hdl.handle.net/2066/65613.

Jerzak, Ethan. 2019. Two ways to want? Journal of Philosophy 116(2). 65-98. https://doi.org/10.5840/jphil201911624. 
Anankastic conditionals are still a mystery

Kratzer, Angelika. 1981. The notional category of modality. In Hans-Jürgen Eikmeyer \& Hannes Reiser (eds.), Words, worlds, and contexts, 38-74. Berlin: de Gruyter. https://doi.org/10.1515/9783110842524-004.

Kratzer, Angelika. 1991. Modality. In Armin von Stechow \& Dieter Wunderlich (eds.), Semantics: An international handbook of contemporary research, 639-65o. Berlin: de Gruyter. https://doi.org/10.1515/9783110126969.7. 639.

Sæbø, Kjell Johan. 1985. Notwendige Bedingungen im Deutschen: Zur Semantik modalisierter Sätze. University of Oslo dissertation. Also published as: Papiere des Sonderforschungbereich 99, vol. 108, Universität Konstanz. https://www.hf.uio.no/ilos/english/people/aca/kjelljs/saeboe-thesis. pdf.

Sæbø, Kjell Johan. 2001. Necessary conditions in a natural language. In Caroline Féry \& Wolfgang Sternefeld (eds.), Audiatur vox sapientiae: A festschrift for Arnim von Stechow, 427-449. Berlin: Akademie-Verlag. https: //doi.org/10.1515/9783050080116.427.

Sæbø, Kjell Johan. 2020. Anankastic conditionals: "If you want to go to Harlem,..." In Daniel Gutzmann, Lisa Matthewson, Cécile Meier, Hotze Rullmann \& Thomas Ede Zimmermann (eds.), The Wiley Blackwell companion to semantics. Oxford: Wiley Blackwell. https:// doi.org/10.1002/ 9781118788516.sem107.

Williams, Bernard. 1981. Moral luck: Philosophical papers, 1973-1980. Cambridge: Cambridge University Press.

Milo Phillips-Brown

Turl St

Oxford OX1 3DW

United Kingdom

milo.phillipsbrown@gmail.com 